\title{
3. Aunty Pearl Gibbs: Leading for Aboriginal rights
}

\section{Rachel Standfield, ${ }^{1}$ Ray Peckham ${ }^{2}$ and John Nolan}

This chapter explores the work of Pearl Gibbs throughout her exemplary career as an activist and tireless campaigner for Aboriginal rights and democracy in Australia from the 1930s until her death in 1983. Pearl's activism on a national level is well documented in the historiography of Aboriginal politics and campaigns for Aboriginal rights, because of her role as a member of the 1930s Aboriginal campaigns for rights and as a member of the Aborigines Progressive Association and their 'Day of Mourning' campaign for Aboriginal citizenship in $1938,{ }^{3}$ as well as her later roles within women's organisations and working with other women campaigners like Faith Bandler, Joan Strack and Jessie Street. ${ }^{4}$ Pearl Gibbs is, however, also remembered in other contexts, and for other reasons, and she is particularly fondly loved and respected by the Aboriginal community in Dubbo, NSW, where she lived for many years, both as a young woman and later in her life.

While she was equally at home in Aboriginal or non-Aboriginal leadership circles, Pearl, we feel, embodied Aboriginal models of leadership. Jackie Huggins' reflections on her own leadership and that of other Aboriginal women offer important insights into the distinctive characteristics of leadership for Aboriginal women. She identifies a leader as one who 'truly' has 'the interests of our community at heart', and when writing of 'our women leaders' recognises that many work behind the scenes and without recognition but for the interests of Aboriginal communities. ${ }^{5}$ And, as Huggins also writes, and as we will also

\footnotetext{
1 Monash University.

2 Elder, Dubbo Community.

3 See, for example, Stephanie Gilbert, “"Never Forgotten”: Pearl Gibbs (Gambanyi)', in Uncommon Ground: White Women in Aboriginal History, eds Anna Cole and Victoria Haskins (Canberra: Aboriginal Studies Press, 2005), 107-26; Sue Taffe, Black \& White Together: FCAATSI, the Federal Council for the Advancement of Aborigines and Torres Strait Islanders, 1958-1973 (Brisbane: University of Queensland Press, 2005).

4 Marilyn Lake, 'Citizenship as Non-Discrimination: Acceptance or Assimilationism? Political Logic and Emotional Investment in Campaigns for Aboriginal Rights in Australia, 1940 to 1970', Gender \& History 13(3) (November 2001): 566-92; Victoria Haskins, “'Lovable Natives" and “Tribal Sisters": Feminism, Maternalism, and the Campaign for Aboriginal Citizenship in New South Wales in the Late 1930s', Hecate 24(2) (1998): 8-21; Victoria Haskins, “"\& so we are 'Slave owners'!": Employers and the NSW Aborigines Protection Board Trust Funds', Labour History 88 (May 2005): 147-64.

5 Jackie Huggins, 'Indigenous Women and Leadership: A Personal Reflection', Indigenous Law Bulletin 6(1) (2004): 1 .
} 
explore through this chapter by considering the relationship of Pearl Gibbs and Ray Peckham, Aboriginal leadership styles often prioritise the intergenerational transfer of both knowledge and responsibility:

It's a very Aboriginal thing to do, to give younger people greater responsibility within the community as they become able to take those responsibilities on. It is a culturally appropriate model that involves respect in both directions - from the younger to the older and the older to the younger. ${ }^{6}$

As Amanda Sinclair notes in this volume, it is vital for feminist scholars of leadership to 'draw attention to the power and privilege reproduced in leadership and leadership research ... They need to continue to fearlessly redirect attention to the ways dominant forms of leadership reinforce the power of a narrow white male elite'. ${ }^{7}$ This is a point that scholars of Aboriginal women's leadership such as Huggins, Larissa Behrendt, Pat $\mathrm{O}^{\prime}$ Shane and Aileen Moreton-Robinson make strongly, but they simultaneously draw attention to the fact that it is the action not only of white men, leaders or otherwise who oppress Aboriginal people, but also of white women. As Behrendt states: Aboriginal women have been oppressed by white women ... White women can be as racist as white men. White women have benefitted economically from the dispossession of Aboriginal people. ${ }^{8}$ Thus, as these Aboriginal women leaders outline, and as Pearl Gibbs' activism shows, Aboriginal women have fought tirelessly against racism, and stress the 'inter-relationship of racism and sexism' for Aboriginal women. ${ }^{9}$

Pearl Gibbs had an incredibly long career of activism and working for democracy. Her activism began when she advocated on behalf of Aboriginal women working as domestic servants in Sydney, where she also worked as a domestic servant from 1917. ${ }^{10}$ She was heavily involved in the Aborigines Progressive Association and was active in the Day of Mourning activities in the sesquicentenary of white settlement in $1938 .{ }^{11}$ She was the first woman to serve

6 Ibid., 4.

7 Amanda Sinclair, Chapter 1, in this volume.

8 Larissa Behrendt, 'Aboriginal Women and the White Lies of the Feminist Movement: Implications for Aboriginal Women in Rights Discourse', The Australian Feminist Law Journal 1 (1993): 31. See also Aileen Moreton-Robinson, 'Tiddas Speakin' Strong: Indigenous Women's Self-Presentation within White Australian feminism', in Talkin' Up to the White Woman: Indigenous Women and Feminism (Brisbane: University of Queensland Press, 2000), 40, 73; Huggins, 'Indigenous Women and Leadership'; and Pat O'Shane, 'Is There Any Relevance in the Women's Movement for Aboriginal Women?', Refractory Girl-A Journal of Radical Feminist Thought 12 (September 1976): 33.

9 Behrendt, 'Aboriginal Women and the White Lies of the Feminist Movement'; Moreton-Robinson, 'Tiddas Speakin' Strong', 73; Huggins, 'Indigenous Women and Leadership'; and O'Shane, 'Is There Any Relevance in the Women's Movement for Aboriginal Women?', 33.

10 Gilbert, “'Never Forgotten"”, 108; Jack Horner, 'Pearl Gibbs: A Biographical Tribute', Aboriginal History 7(1) (1983): 12 .

11 Gilbert, “"Never Forgotten"”, 108; Horner, 'Pearl Gibbs', 14. 
on the NSW Aborigines Welfare Board, from 1954 to $1957 .{ }^{12}$ She was founding vice-president of the Aboriginal-Australian Fellowship from 1956, and this organisation was incredibly active in petitioning government for constitutional change for Aboriginal people, culminating in the 1967 referendum. ${ }^{13}$ She was instrumental in reviving the Aborigines Progressive Association in 1963 as an Aboriginal-controlled organisation which drew on the experiences of Aboriginal communities outside Sydney. ${ }^{14}$ She was also an excellent networker and mentor and made use of the media as a channel to both appeal to and remind nonAboriginal people of their responsibilities to extend the benefits of Australian democracy and living standards to Aboriginal people. ${ }^{15}$ Her campaigning, and particularly her speaking and media work, to demand Aboriginal rights was based on bringing the experiences of Aboriginal communities to light on the national stage, to make non-Aboriginal people focus on the real conditions Aboriginal people faced in New South Wales and to compel non-Aboriginal people to act to change those circumstances. ${ }^{16}$

In this chapter, we wish to document and explore the significance of Pearl's work in Aboriginal communities in general, but particularly in Dubbo, through a combination of the memories of two people particularly close to Pearl: Ray Peckham, Dubbo elder and himself an important campaigner for Aboriginal rights from the 1950s, and John Nolan, who knew Pearl from his childhood and later went on to work with her at the first Aboriginal hostel in Dubbo, as well as her legacy for the Dubbo Aboriginal community. This chapter has developed from a presentation given by John and Ray to the elders meeting at the Centre for Aboriginal Studies at Charles Sturt University (CSU) in 2011, which celebrated Pearl's life and her place as a member of the Aboriginal community in Dubbo, which Rachel Standfield attended in her capacity as a lecturer at CSU. ${ }^{17}$ John and Ray spoke with love and respect about their relationships with Aunty Pearl, who lived in Dubbo for long periods of her life and during her later life until her death in 1983, and worked with members of the Dubbo Aboriginal community.

This presentation prompted the three of us to work together to consider Pearl's role and to undertake additional research amongst Pearl Gibbs' papers at the Mitchell Library in Sydney, and from there to present as a panel to the Women

\footnotetext{
12 Sue Taffe, 'Pearl Gibbs', Collaborating for Aboriginal Rights website (Canberra: National Museum of Australia, 2008), http://Aboriginalrights.net.au/person.asp?pID $=966$.

13 Sue Taffe, 'Aboriginal-Australian Fellowship', in ibid., http://Aboriginalrights.net.au/organisation. asp?oID $=1$.

14 Sue Taffe, 'Aborigines Progressive Association', in ibid., http://Aboriginalrights.net.au/organisation. asp?oID $=30$.

15 Pearl presented the first radio broadcast by an Aboriginal woman, on Sydney radio station 2GB in 1941. A transcript is included in Kevin J. Gilbert, Because a White Man'll Never Do It (Sydney: Angus \& Robertson, 1973), 13-17.

16 Pearl's papers include both her own media work and clippings relating to Aboriginal issues in general.

17 Rachel wishes to extend her sincere thanks to John and Ray for their support, their patience and their friendship.
} 
in Democracy conference. In this chapter, we bring together Rachel's research carried out within Pearl's papers with the memories of Ray and John. We aim to provide a sense of the way Pearl's advocacy for Aboriginal rights and democracy was informed by knowledge of, and work with, Aboriginal communities, and to outline how she inspired and challenged other people, both Aboriginal and nonAboriginal, to be active for Aboriginal rights, to campaign for and support civil rights and rights as Aboriginal peoples. We consider the way Pearl worked to bridge the gap between Aboriginal communities and the non-Aboriginal public, first through the provision of information to Aboriginal communities and the wider non-Aboriginal community through the collection of information and strategic use of the media to publicise Aboriginal issues. We also wish to explore the way Pearl worked to bring positive changes for the Dubbo community and to create new generations of Aboriginal activists by remembering Pearl's role shaping Ray Peckham's activism, and the way she worked with non-Aboriginal campaigners while at the same time keeping them 'honest' in their role.

In looking at the way Pearl connected with communities, we are following a point made by Marilyn Lake about the need to look at the community basis of movements for change, including of course the women's movement and campaigns for Aboriginal rights, which 'have been', Lake writes, 'community based, drawing their strengths from a very diverse range of ordinary people in ordinary communities'.$^{18}$ Other papers regarding Aboriginal women's leadership delivered at the Women, Leadership and Democracy conference made similar points, with Pat Dudgeon stressing that 'Aboriginal women's leadership is concerned about community', Gwenda Baker writing about Aboriginal women's community leadership and Noah Riseman providing insight into Sue Gordon's work for her own WA communities. ${ }^{19}$ Pearl's own diverse experiences in Aboriginal communities in Sydney and in country New South Wales informed her activism and allowed her to provide a particularly powerful, and grounded, realism to her calls to action.

Pearl worked tirelessly for the Aboriginal community in Dubbo, working with and for local community members in their struggle for rights. Pearl was connected to Aboriginal communities in western New South Wales and particularly to Dubbo for significant periods of her life. Dubbo was the home of William Ferguson, with whom Pearl had a close relationship in their work with the Aborigines Progressive Association, and meetings had been held there. Pearl's connection with Dubbo and her work for the Dubbo Aboriginal communities continued when she returned to Dubbo to live later in life, moving there with her sister and mother in the late 1940s. She became caretaker and a

18 Marilyn Lake, ‘Founding Fathers, Dutiful Wives and Rebellious Daughters, 2001 Eldershaw Memorial Lecture', THRA Papers and Proceedings 48(4) (December 2001): 268-79.

19 See Gwenda Baker, Joanne Garngulkpuy and Kathy Guthadjaka, Chapter 2, this volume. 
leader, a 'grandmother-type figure' to the many Aboriginal people who would come to stay from out west at the Dubbo Aboriginal Hostel, which she had been instrumental in establishing in 1958.

John had the opportunity to meet Pearl after the Aboriginal Hostel in Bembrose Lane, North Dubbo, was built and opened in the latter part of the 1950s. Eva Shipp was the first caretaker followed by Eric Mason, a regional officer employed by the Aborigines Welfare Board, and then Pearl Gibbs. Pearl's role was caretaker of the premises and she lived rent-free until the land was transferred to the NSW Aboriginal Lands Trust in 1975. John's employment with the NSW Aboriginal Land Trust connected him to Pearl as her landlord, which meant he became the collector of the rent Pearl was now expected to pay, and was in charge of all maintenance and care of the building and grounds. Pearl was a formidable lady, and readers might well imagine the difficulties John faced explaining to Pearl the reason she had to now start paying rent. It took John seven and a half years to finally convince Pearl why she had to pay rent, even though he tried repeatedly and insistently over the years to convince the Aboriginal Lands Trust that this special lady should be treated with much respect and be offered rent-free accommodation as caretaker.

\section{Pearl's papers: Building and remembering activism}

Pearl's trunks full of papers - which are now housed in the Mitchell Librarywere important artefacts in Pearl's work. Pearl collected newspaper articles about Aboriginal issues, including articles in which the work of Aboriginal campaigners including herself was reported, along with other memorabilia, and she used this collection to bring Aboriginal issues to the attention of people she encountered, to encourage others to also work to promote Aboriginal rights and to relive histories of activism, including her own. They became the basis not only of activism but also of memory; those who knew Pearl in Dubbo had been taken through these papers, regaled with stories of the history of Aboriginal activism, and encouraged to engage with the struggle. These trunks are central to John's memories of Pearl and hours spent in her company; the hostel where Pearl lived was also her 'live-in library', and her old tin trunks full of paper also included clippings and documents from her involvement with the Aborigines Welfare Board and many other organisations with which she had an association. For more than seven years, as Pearl's landlord, John spent many long hours sitting with her as she would direct him to go to a certain trunk under one of the beds, select certain clippings and read an article in its entirety. John remembers this as a very rewarding part of his job as rent collector. There were numerous articles showing photographs that he had never seen before and some were very 
telling; he remembers clearly photographs of Aboriginal tribal men in chains, and, on the periphery, Aboriginal trackers adorned in a type of police uniform but never being seen as 'the real deal'.

These papers constituted an important part of the struggle for Aboriginal rights in Pearl's work. Heather Goodall relates how Pearl used media information to keep Aboriginal communities abreast of campaigning for Aboriginal rights and as a catalyst to collect more evidence to be used in that struggle. Pearl returned to Brewarrina Station, where she had grown up and had relatives living, for the Christmas period in 1937, taking with her

the clippings from the Aboriginal movement's successful press campaign in October and the newspapers were secretly passed so eagerly from person to person on the station that they disintegrated from handling while Pearl was there. Intending to gain further evidence for the Select Committee, Pearl spoke mainly with the women, who talked of the poor food, the sexual abuse of the dormitory girls and the insanitary conditions of the treatment room. ${ }^{20}$

In Pearl's speech to the Aborigines conference of the 1938 Day of Mourning, this evidence from the people living on Brewarrina Station became part of the campaign. She had taken the media reports of Aboriginal campaigns to Brewarrina, using it to collect more information, which became further evidence for the citizenship campaign:

At Brewarrina the children are taught by a man who is not a qualified teacher. Two old men on that station, one blind, the other a cripple, are left by themselves in a half-starved state. The manager of the Station and others get milk from five cows, but the old men get only condensed milk. I spoke to these old men, and when they told me how badly they were treated it made me cry, and pray that this movement will be a success. ${ }^{21}$

Pearl's invocation of this emotionally touching scene of elderly men on the station at Brewarrina typified her role in the actions of the Aborigines Progressive Association, in which she was an outspoken speaker on what were considered 'women's issues'. Her words invoked the emotions of her listeners to relive her experiences with people on the Brewarrina Station to appeal for citizenship rights.

20 Heather Goodall, Invasion to Embassy: Land in Aboriginal Politics in New South Wales, 1770-1972 (Sydney: Allen \& Unwin, 1996), 212-13.

21 'Our Historic Day of Mourning and Protest: Aborigines Conference', The Abo Call, April 1938: 2, http:// www.aiatsis.gov.au/collections/exhibitions/dayofmourning/images/pdf/a334816_s04_m.pdf. 
These old men are absolutely neglected. Though on the Reserve, I know that no manager visited them for ten days ... I explained the meaning of full citizenship rights to these old men, and they knew that they would be better off with full citizenship rights than under the Protection Board, because they would get Old Age Pension and proper medical attention. ${ }^{22}$

When Ray Peckham came to work with her in Sydney, Pearl sent him to Central Station every morning to get newspapers from all over the State, and to scour them for information about Aboriginal issues, cutting, pasting and labelling the articles into scrapbooks of clippings. An example of her use of her trunks full of papers to document the struggle for Aboriginal rights was provided in New Dawn when the editor met with Pearl in Dubbo as he travelled into western New South Wales. Pearl sat him down and took him through her papers:

With a shock, I realized, as I turned the pages, that the dates on these cuttings were 1938, 1939. I wasn't even born then. In the days when Aborigines kept quiet on reserves and rarely spoke up, Pearl Gibbs was already speaking at public functions about the conditions under which her people were living. As she talked, she showed, indirectly, how the frustration built up in her over the years. Yes, there was progress, she admits, but how slow, how slow. I picked up the book of Human Rights and read out the sonorous, beautiful words, slowly: 'All human beings are born free and equal in dignity and rights. They are endowed with reason and conscience and should act towards one another in a spirit of brotherhood.'

Pearl, a quarter-caste, laughs. 'You wonder what I've got that for, eh? Don't you see? I have to be interested in citizenship rights. I'm not quite white enough to be able to ignore them. ${ }^{23}$

\section{Pearl Gibbs: Bringing Aboriginal communities to the attention of the non-Aboriginal public}

Pearl's own diverse experiences in Aboriginal communities in Sydney and throughout New South Wales informed her activism and allowed her to provide a particularly powerful, and grounded, realism to her calls to action. Pearl was an expert public speaker and made excellent use of the media, and especially women's media, to create empathy towards and action for Aboriginal people. In agitating for this change, Pearl explicitly expressed her role in both white and Aboriginal worlds. For example, in a letter to the Nowra Leader in 1940, written

22 Ibid.

23 'Stopping off at Dubbo on the Track West...', New Dawn, January 1971, 7. 
when she was living on the NSW South Coast, ${ }^{24}$ and in which she took on the manager of the Brewarrina Reserve about conditions faced by Aboriginal people there, Pearl set out her speaking position thus: 'as a person of aboriginal blood, I have a knowledge of our customs, laws and traditions; also a white person's outlook to the questions.'

But she stressed that she spoke as someone who was connected to communities throughout New South Wales:

I know La Perouse, Roseby Park, Wreck Bay, Wallaga Lakes, and various other aborigine stations, she said. I also know Brewarrina very well. The bad housing, water supply, appalling sanitary conditions, lack of proper education, lack of food, along with unsympathetic managers, make life not worth living for my unfortunate race ... Our men fought for democracy and Christianity in 1914-1918, and are doing the same today. Oh, no, Mr Paul, the A.P.B. [Aborigines Protection Board] is not doing the fine job you would have the public believe. ${ }^{25}$

Pearl bridged the gap between the lives of those people who themselves did not have enough power or a voice to be able to fight for rights and the wider community. As Pearl herself recounted to Heather Goodall later in her life in relation to her advocacy for Aboriginal girls in domestic service in Sydney homes: 'A lot of them were helpless and intimidated: they weren't allowed to be responsible.' And Pearl took it upon herself to use her confidence, her voice and her anger at the conditions Aboriginal people were subjected to, to advocate on behalf of people who couldn't advocate for themselves. ${ }^{26}$ This was a world into which she invited the media, and, through the media, the nonAboriginal public to share the experiences of Aboriginal people, to understand the situation of Aboriginal people and to work to extend citizenship rights to the whole community.

In April 1938, Pearl penned a letter to the editor of the Woman Today in which she called on her 'white sisters' to become a part of campaigns for Aboriginal rights. 'I am appealing to you', she wrote,

on behalf of my people to raise your voices with ours and help us to a better deal in life ... Surely you are not so callous to ignore our plea. Those of my people living in the more civilised parts of Australia are

\footnotetext{
24 'Newsworthy', Woman, 16 June 1941, Scrapbook of newscuttings, c. 1938-1946, MS6922/3X item 1, CY4043, frame 40, Pearl Gibbs Papers, Mitchell Library, Sydney [hereinafter Gibbs Papers].

25 Letter from Pearl Gibbs, 'Case for the Aborigine', to Mr Norman Paul, Aborigine Station, Brewarrina, Nowra Leader, 21 June 1940, Scrapbook of newscuttings, c. 1938-1946, MS6922/3X item 1, CY4043, frame 37, Gibbs Papers.

26 Heather Goodall, 'Three Tributes to Pearl Gibbs (1901-1983)-Pearl Gibbs: Aboriginal Patriot', Aboriginal History 7(1) (1983): 21.
} 
not asking for the stone of anthropology - but for practical humanity, for the opportunity to feed our children properly, to educate them; in a word, to grant them all the rights and responsibilities of democracy. ${ }^{27}$

And in response the Woman Today sent a reporter to talk to Pearl as she waited at Parliament House as part of an Aborigines Progressive Association delegation to talk to parliamentarians about citizenship rights. They did so, as they said, because 'from the letters we receive, we know there are many more women suffering the effects of unjust social conditions, whom we should interview, that we may aid them by giving publicity to their wrongs'. Pearl's heartfelt letter had worked: Woman Today came to ask Pearl to outline the discrimination faced by Aboriginal people. She talked about the lack of unemployment benefits, outlining Aboriginal hunger on the missions, the lack of access women had to the baby bonus and, of course, the constant fear women had that their children would be removed-all from the perspective of people she knew personally. The interviewer stressed that she had 'never had the opportunity of talking to anyone as closely related with the Aborigines as you are' ${ }^{28}$

Twenty years later, as Pearl came to work with the Aborigines Welfare Board, her papers contain another significant interview Pearl conducted, for the union magazine Our Woman in 1956. The interview took a different style, but still with the same underlying approach of bringing non-Aboriginal women into the lives of Aboriginal people, to call for action on the basis of common humanity and to bridge the gap between the two communities. As Pearl stated in the beginning of the interview, '[m]y people do not ask for sympathy ... we have had that since Captain Cook landed. What we want is justice. ${ }^{29}$ And in the search for justice Pearl took the reporter into another of her communities, that of La Perouse. Pearl conducted the reporter to the home of a young mother and her family, and then took the reporter to a concert of performances by young people.

The reporter, Mary Rafferty, expressed her excitement at being able to engage with Aboriginal people: 'I had not met many Aborigine people, and certainly not seen them "at home". Besides, Mrs Gibbs is the only Aborigine Member of the NSW Aborigines' Welfare Board ... Seeing an Aborigines Settlement in her company would be something different. ${ }^{\prime 30}$

The experience had a significant impact on Rafferty, who wrote the following when meeting a young couple, Linda and Roy, and their baby girl Muriel:

\footnotetext{
27 Pearl Gibbs, 'An Aboriginal Woman Asks for Justice', [Letter], Woman Today, April 1938, Scrapbook of newscuttings, c. 1938-1946, MS6922/3X item 1, CY4043, frame 16, Gibbs Papers.

28 Sally Bannister, 'Our Aboriginal Sisters: Appeal for Justice for their Unhappy Race', Woman Today, May 1938, Scrapbook of newscuttings, c. 1938-1946, MS6922/3X item 1, CY4043, frame 21, Gibbs Papers.

29 'Justice, Not Sympathy', Our Women, March-May 1956, 4, newspaper cutting, Gibbs Papers.

30 'Binya', Our Women, March-May 1956, 18, newspaper cutting, Gibbs Papers.
} 
[W] hat a lovely young mother she was! She gave me the baby. Holding her close, stroking the thick black hair, and admiring the dainty little features, I wanted to stay longer and go on talking to the family ... they were so friendly, made me feel right at home ... Pearl of course was an old friend, but I felt even had she not been there I would not have felt any less at ease. ${ }^{31}$

\section{Ray Peckham and Pearl Gibbs: Mentoring and activism}

Ray Peckham became an activist for Aboriginal rights because of the encouragement and energy of Pearl Gibbs. ${ }^{32}$ He first met her when he was about four or five years of age at the old Talbragar mission about $5 \mathrm{~km}$ north of Dubbo, never realising then that one day he would be working with her. Ray was living in Sydney when he was approached by Pearl Gibbs to attend the Berlin Youth Festival. When Ray decided to move to Sydney, where Pearl was also living, she was his only contact in the city. On his arrival, Pearl greeted him and declared: 'I've been waiting for one of you bastards to come down here and give me a hand.' Pearl took Ray to Trades Hall the next day-his first introduction to trade unions. Ray became a builder's labourer, and worked with Jack Mundey, known for introducing the green bans on the Sydney Harbour foreshore.

When Ray arrived in Sydney, the only Aboriginal organisation was the Aboriginal-Australian Fellowship. Pearl had worked with Faith Bandler to establish this organisation four years before, but was conscious that the fellowship was based in Sydney and had limited contact with Aboriginal people outside the metropolitan area. Pearl's work as the only Aboriginal representative and the first Aboriginal woman on the 12-member Aborigines Welfare Board, serving a three-year term from 1954 to 1957, had made her frustrated at having any progressive suggestions overruled. As she described to the 1961 conference of the Aboriginal-Australian Fellowship: 'I am the only woman who has represented the Aborigines on the Welfare Board, and it was a very difficult job trying to stand up against those men who are so well educated and have high positions. ${ }^{33}$ An example of the gulf between the situation of the white men on the Welfare Board and the circumstances faced by Pearl as an Aboriginal woman are outlined in a story related by Pearl to Heather Goodall:

31 Ibid.

32 Ray's presentation to the women and democracy conference, where he presented on his relationship to Pearl, was recorded. This recording is available via the Museum of Australian Democracy.

33 Aboriginal-Australian Fellowship, Records, 1956-1978, Mitchell library MLMSS 4057, Box 3, 'Aborigines and Ourselves' conference 1961 convened by the Aboriginal-Australian Fellowship, Reports and discussion, 15. 
[Pearl] enjoyed telling the story of the first Christmas of her term, in 1954, in which the white Board members, all senior male bureaucrats or academics, invited her to 'share some frivolities'. Pearl was very aware of the tensions of the situation, and waited until the Board members offered her a Christmas drink. Then she pointed out to them: 'I don't have an exemption certificate, and as you've heard repeatedly, it's only low down white men that give grog to black women'. ${ }^{34}$

A major problem during her time on the Welfare Broad, in her quest to continue connecting with communities, was the restrictions placed on her travel. She was restricted to just two tickets a year, and on one occasion was invited to tour some reserves with the secretary of the board-a trip that would ensure she only saw the best of reserve conditions and could not speak frankly with Aboriginal people about their lives. ${ }^{35}$ These restrictions of course meant she could not engage with communities and understand their concerns; they were a key way the board sought to limit her effectiveness and constrain her in her role.

Her work with the Welfare Board and the Aboriginal-Australian Fellowship had thus convinced her of the need to re-establish an Aboriginal-controlled organisation and she emphasised to Ray that the 'first thing we have to do is reintroduce the old Aborigines Progressive Association', to 'get back over the mountain' where people were 'screaming out' for help and leadership. Ray and Pearl made trips to Aboriginal communities west of Sydney to revive the association.

Pearl's influence was central to Ray's activism, through her choice of him as an Aboriginal delegate to attend the Berlin Youth Festival in 1951. The World Federation of Democratic Youth had called for delegates, with Pearl interviewing Aboriginal candidates, but knocking back a number who were keen to take their girlfriends or spouses with them because the costs had to be paid up-front and reimbursed later. About a fortnight before the ship sailed, Ray and Pearl were at a fundraising dance in Sydney. Pearl was becoming anxious as to who would attend the festival after having received a cable asking her to name the delegate. She looked around and at Ray and asked 'would you go?' She was pleased when he replied, 'I wouldn't go anywhere unless I went home to Dubbo to ask Mum', and she sent him on the midnight train to Dubbo to ask permission, and was waiting on the platform when he returned 24 hours later. Ray was lucky his mother knew a Russian woman who assured her that he would be treated well when he travelled behind the Iron Curtain, and his mother gave him permission

34 Heather Goodall, “Assimilation begins in the Home”: The State and Aboriginal Women's Work as Mothers in NSW, 1900 to 1960s', Labour History (69) (November 1995): 75.

35 Letter from M. H. Saxby, Superintendent of the Aborigines Welfare, to Pearl Gibbs, Aborigines Welfare Board, Sydney, 27 September 1954, Letters and Cards received 1953-1983, MLMSS 6922, Box 1, Gibbs Papers. 
to go. The trip almost didn't happen when Ray's passport was not processed in time. On 2 June 1951, Ray was on board the ship waiting to go but still without a passport, until the trade unions - the Waterside Workers, the Building Workers Industrial Union, the Builders' Labourers and the Maritime Workers' Unionrefused to let the ship leave Sydney Harbour without Ray, or any other ships leave harbours around Australia. The ship was delayed for four hours until the passport was provided and Ray could travel to the festival.

Ray attended with 95 other young Australians from around the country. He and Brian Thomas were the Aboriginal delegates, and Faith Bandler also attended. They sailed from Fremantle to their first stop in Colombo, Ceylon (Sri Lanka), where, as in all ports they would subsequently stop, they were met and hosted by local young people and shown sites of interest. Ray celebrated his twentyfirst birthday between Colombo and their next stop of Bombay, and the ship then sailed through the Suez Canal to London, and they then travelled across Europe, and Ray remembers fondly travelling through Italy before the festival. After the festival he travelled with other delegates in the USSR.

This was a formative experience in Ray's life, which he can now look at as being like a huge tree that started with the planting of a seed by William Ferguson in Dubbo when Ray was only a very small boy, and from then to now the tree has grown, and has blossomed. Ray considered the results of this work are shown by the number of Aboriginal students currently enrolled at Charles Sturt University, where Ray continues to work, in particular working closely with elders locally and from across the nation.

\section{Pearl and non-Aboriginal activists}

Pearl worked to build community between Aboriginal and non-Aboriginal people as she did through her media and speaking work, but she was very careful to ensure that this community was one which suited Aboriginal people, and in which Aboriginal people spoke for themselves. Her media and speaking work may have tried to create new non-Aboriginal activists on behalf of Aboriginal causes, but once those people were committed, Pearl was staunch in her insistence that non-Aboriginal activists work for Aboriginal people; she insisted that Aboriginal concerns and views were always central. When she was interviewed in the New Dawn in the early 1970s and the interviewer wrote somewhat sarcastically that Pearl had 'educated' him, non-Aboriginal activists Len Fox and Jack Horner both wrote letters to the paper applauding her work and remembering the way she had also 'educated' them. Fox wrote about a meeting with her in 1950: 
Pearl started, 'it's all your fault you know', she said, 'it's you whites who are to blame' ... She hammered 'you whites' for the whole half hour til the others arrived and I just had to sit there and take it.

It seemed a bit tough that I was the only white in Sydney who had come along to do something about it and here I was getting the blame. But I knew Pearl's stirring record of fighting for her people day in and day out, year after year, and although I took a lot of abuse that night it remains a happy memory. I've never lost my respect for Pearl and her tireless struggle for the dignity of her people. ${ }^{36}$

Horner wrote in a similar vein:

I see that you have been educated by Pearl Gibbs. We were all educated by Pearl at one time or another ... When I was active in Sydney years ago, Pearl was one of the koories who kept a watchful eye to make sure that I did not get away with any white man's humbug. At the slightest sign of it, or of pushing a line that was not the way the kooris saw it, I was jumped on. Then it was explained to me, that I was expected to write my letters and make my protests exactly as they wanted. ${ }^{37}$

Pearl insisted that non-Aboriginal activism for Aboriginal causes was not about non-Aboriginal people themselves, but always about, and for, the Aboriginal community. In doing so she placed Aboriginal experiences at the forefront and demanded that non-Aboriginal activists accede to the needs of Aboriginal communities, ensuring they recognise their own complicity in Aboriginal disadvantage.

In this sense, as in her other work, Pearl may have been an important national figure, but she was always clear whom she worked for, and she made sure others were clear on this too. Pearl's activism attempted to connect Aboriginal and non-Aboriginal people, bringing the real circumstances faced by Aboriginal communities into the consciousness of non-Aboriginal Australia to agitate for citizenship, democracy and Aboriginal rights. Her work for communities was tireless and she is truly a woman who exemplifies leadership for democracy in this country.

36 Len Fox, 'Letter to the Editor', New Dawn, June 1971: 15.

37 Jack Horner, 'Letter to the Editor', New Dawn, June 1971: 15. 
Diversity in Leadership: Australian women, past and present

\section{References}

Aboriginal-Australian Fellowship. Records 1956-1978. MLMSS 4057, Mitchell Library, Sydney.

Behrendt, Larissa. 'Aboriginal Women and the White Lies of the Feminist Movement: Implications for Aboriginal Women in Rights Discourse.' The Australian Feminist Law Journal 1 (1993): 27-44.

Fox, Len. 'Letter to the Editor.' New Dawn, June 1971: 15.

Gibbs, Pearl. Papers. MS 6922/3X, Mitchell Library, Sydney.

Gilbert, Kevin J. Because a White Man'll Never Do It. Sydney: Angus \& Robertson, 1973.

Gilbert, Kevin. 'Three Tributes to Pearl Gibbs (1901-1983)-Pearl Gibbs: Aboriginal Patriot.' Aboriginal History 7(1) (1983): 5-9.

Gilbert, Stephanie. “'Never Forgotten": Pearl Gibbs (Gambanyi).' In Uncommon Ground: White Women in Aboriginal History, edited by Anna Cole and Victoria Haskins, 107-26. Canberra: Aboriginal Studies Press, 2005.

Goodall, Heather. 'Three Tributes to Pearl Gibbs (1901-1983)—Pearl Gibbs: Aboriginal Patriot.' Aboriginal History 7(1) (1983): 20-2.

Goodall, Heather. "Assimilation begins in the Home": The State and Aboriginal Women's Work as Mothers in NSW, 1900 to 1960s.' Labour History 69 (November 1995): 75-101.

Goodall, Heather. Invasion to Embassy: Land in Aboriginal Politics in New South Wales, 1770-1972. Sydney: Allen \& Unwin, 1996.

Haskins, Victoria. "Lovable Natives" and "Tribal Sisters": Feminism, Maternalism, and the Campaign for Aboriginal Citizenship in New South Wales in the Late 1930s.' Hecate 24(2) (1998): 8-21.

Haskins, Victoria. "“\& so we are 'Slave owners'!": Employers and the NSW Aborigines Protection Board Trust Funds.' Labour History 88 (May 2005): 147-64.

Horner, Jack. 'Letter to the Editor.' New Dawn, June 1971: 15.

Horner, Jack. 'Pearl Gibbs: A Biographical Tribute.' Aboriginal History 7(1) (1983): 10-20.

Huggins, Jackie. 'Indigenous Women and Leadership: A Personal Reflection.' Indigenous Law Bulletin 6(1) (2004): 5-7. 
Lake, Marilyn. 'Citizenship as Non-Discrimination: Acceptance or Assimilationism? Political Logic and Emotional Investment in Campaigns for Aboriginal Rights in Australia, 1940 to 1970.' Gender \& History 13(3) (November 2001): 566-92.

Lake, Marilyn. 'Founding Fathers, Dutiful Wives and Rebellious Daughters, 2001 Eldershaw Memorial Lecture.' THRA Papers and Proceedings 48(4) (December 2001): 268-79.

Moreton-Robinson, Aileen. 'Tiddas Speakin' Strong: Indigenous Women's SelfPresentation within White Australian Feminism.' In Talkin' Up to the White Woman: Indigenous Women and Feminism, 150-78. Brisbane: University of Queensland Press, 2000.

O'Shane, Pat. 'Is There Any Relevance in the Women's Movement for Aboriginal Women?' Refractory Girl-A Journal of Radical Feminist Thought 12 (September 1976): 31-4.

'Our Historic Day of Mourning and Protest: Aborigines Conference.' The Abo Call, April 1938: 2. http://www.aiatsis.gov.au/collections/exhibitions/ dayofmourning/images/pdf/a334816_s04_m.pdf.

Peckham, Ray. Presentation to the Women, Leadership and Democracy in Australia Conference, Museum of Australian Democracy, Old Parliament House, Canberra, 1-2 December 2011.

'Stopping off at Dubbo on the Track West...' New Dawn, January 1971: 7.

Taffe, Sue. Black \& White Together: FCAATSI, the Federal Council for the Advancement of Aborigines and Torres Strait Islanders, 1958-1973. Brisbane: University of Queensland Press, 2005.

Taffe, Sue. Collaborating for Aboriginal Rights website. Canberra: National Museum of Australia, 2008. http://indigenousrights.net.au/default.asp. 
This text taken from Diversity in Leadership: Australian women, past and present, edited by Joy Damousi, Kim Rubenstein and Mary Tomsic, published 2014 by ANU Press, The Australian National University, Canberra, Australia. 